\title{
G
}

Entrepreneurial Business and Economics Review

2013, Vol. 1, No. 4

\section{Editorial: Modern Challenges for Business and Economy in CEE Countries}

In recent years the phenomenon of globalisation has become an important issue, widely discussed in the academic literature. Debates explore globalisation intensity and its consequences for economies and businesses around the world. According to A.V. Rutkauskas (2013, p. 388), the processes of globalisation "inevitably determine the integration of countries and regions, which empowers a more economic use of natural resources, more efficient creation of new resources and the increase in the effectiveness of human resource and technology utilization". Nevertheless, in the short-range perspective, the uncontrolled processes of globalisation reveal various problems, solution of which requires extra expenditures.

Thus, looking at the process of globalisation, it is possible to notice growing number of challenges that need to be coped with by governments, businesses and societies in various parts of the world (Mascarenhas, 2009). The region of Central and Eastern Europe (CEE) is not an exception from the rule. Moreover, due to different facets of globalisation and regionalisation, some challenges are similar to those in other parts of the world, although the region has its own specific problems to solve and consider on the way to success (Klich, 2013; Renko \& Knezevic, 2013).

Consequently, this issue of EBER concentrates on the modern challenges for organisations and countries' economies in the region of the CEE, particularly four countries: Lithuania, Poland, Russia and Slovakia. First part consists of three research papers related to scientific methods' utilisation, and concentrates on the following challenges: public debt management, investing on global market, and searching for better models estimating the cost of equity in emerging markets. Second part includes four articles dealing with exploration of the following topics: cooperation of businesses on international markets, collaboration between public and private sectors, peculiarities of income taxation and entrepreneurship opportunities after military service.

First paper, Implementation of Multi-Objective Evaluation Method in Public Debt Risk Management, prepared by Jelena Stankevičienè and Sergej Rosov is devoted to analysis and developing a public debt risk assessment model, which allows predicting country's economic well-being trends. The proposed model evaluates different aspects of public debt-related structural indicators.

Second paper, Investment Decisions in Global Financial Markets: the Experience of Lithuania of Aleksandras Vytautas Rutkauskas and Alina Kvietkauskienè, deals with identifying investment decision making scheme under globalisation processes in financial markets. The universal method of investment is offered in order to save the interests of investors. Moreover, the authors have argued that adequate portfolio model can be utilised in Central and Eastern Europe for investment decision-making in global financial markets. 
Third article, An Empirical Study of Unsystematic Risk Factors in the Capital Asset Pricing Model: the Case of Russian Forestry Sector prepared by Varvara Nazarova, investigates the Capital Asset Pricing Model (CAPM), determining its most disputable aspects. The experimental part of the study has been performed by calculating models for three options of implementing the investment projects and the assessment of the total impact of reducing non-systematic risks for the Russian forestry sector.

Peculiarities of Labour Income Taxation in the Baltic States by Ilona Skačkauskienè aims at identifying the peculiarities of the taxation of labour income in the Baltic States (Lithuania, Latvia and Estonia). The outcomes of the conducted research have proven that the comparison of the basic tax indicators, such as non-taxable minimum income and standard rates, only to some extent illustrates the national level of the labour income taxation.

Collaborative Advantage in Public and Social Services: the Case of Poland by Maria Janina Szymankiewicz analyses the relationships between the third and the public sector, with a particular focus on relations with local government units (LGUs), based on the example of Poland. Moreover it also demonstrates a useful tool which facilitates the realisation of such a task - a model of strategic cross-sector collaboration.

Cooperation and Its Role in Facilitation of Foreign Expansion: Example of Slovak Enterprises by Mária Šášiková and Tatiana Hlušková concentrates on pointing out the importance of cooperation between business companies in order to facilitate the process of their internationalization, and is based on the example of Slovak-foreign joint ventures. The findings imply that the Slovak companies' cooperation with foreign enterprises can result in a successful business.

The final paper, Entrepreneurship Opportunities after Military Career: Practice in Central and Eastern versus Western Europe by Rasa Smaliukienè, deals with an important issue of existing practices of entrepreneurship skills development of early retired servicemen in EU member countries and evaluate the differences between Central and Eastern Europe and Western Europe practice. The findings indicate the lack of entrepreneurship development policies for early retired servicemen, in spite of the fact that service in military frequently provides very specific competencies that could be adapted as transferable expertise and knowledge for entrepreneurship.

\section{Marek Szarucki \\ Issue Editor}

\section{REFERENCES}

Klich, J. (2013). Editorial: Modern challenges for international business in Europe. Entrepreneurial Business and Economics Review, 1(2), 5-6.

Mascarenhas, B. (2009). The emerging CEO agenda. Journal of International Management, 15(1), 245-250.

Renko, S., \& Knezevic, B. (Eds.). (2013). Challenges for the Trade of Central and Southeast Europe (International Business and Management, Volume 29), Bingley: Emerald Group Publishing Limited.

Rutkauskas, A. V. (2013). Integrated management of migration, employment, fiscal policy and public debt. Business, Management and Education, 11(2), 376-390. 